\title{
EFEKTIVITAS KARBON AKTIF DALAM PEMBUATAN GARAM RUMPUT LAUT COKELAT (Sargassum polycystum DAN Padina minor)
}

\author{
Shindy Hamidah Manteu *, Nurjanah, Asadatun Abdullah, \\ Tati Nurhayati, Anggrei Viona Seulalae \\ Departemen Teknologi Hasil Perikanan, IPB University, Jalan Agatis, Kampus IPB Dramaga \\ 16680 Bogor
}

Diterima: 25 September 2021/Disetujui: 31 Desember 2021

*Korespodensi: shindyhamidah27@gmail.com

Cara sitasi: Manteu SH, Nurjanah, Abdullah A, Nurhayati T, Seulalae AV. 2021. Efektivitas karbon aktif dalam pembuatan garam rumput laut cokelat (Sargassum polycystum dan Padina minor). Jurnal Pengolahan Hasil Perikanan Indonesia. 24(3): 407-416.

\section{Abstrak}

Rumput laut cokelat memiliki potensi menjadi bahan baku garam diet untuk hipertensi, namun terdapat permasalahan dari produk akhir garam rumput laut yaitu aroma khas rumput laut (amis) yang masih kuat. Salah satu cara yang dapat dilakukan dalam meminimalisasi permasalahan tersebut adalah penambahan bahan alami yang berperan dalam menghilangkan bau. Karbon aktif merupakan salah satu bahan alami dan tidak toksik yang berperan dalam menghilangkan bau dan bertindak sebagai adsorben. Tujuan penelitian ini adalah menentukan konsentrasi karbon aktif dalam proses pembuatan garam S. polycystum dan $P$. minor untuk menghasilkan garam yang bisa diterima oleh masyarakat. Metode yang digunakan dengan perlakuan konsentrasi karbon aktif berbeda $(0 \%, 0,50 \%, 0,75 \%, 1 \%, 1,25 \%, 1,50 \%(\mathrm{~b} / \mathrm{v}))$ pada proses pembuatan garam, uji sensori aroma, dan karakterisasi garam rumput laut. Karakteristik garam meliputi kadar mineral ( $\mathrm{Mg}, \mathrm{Fe}, \mathrm{Ca}, \mathrm{Na}, \mathrm{K}$ ), rasio $\mathrm{Na}: \mathrm{K}$, kadar $\mathrm{NaCl}$ dan aktivitas antioksidan. Konsentrasi karbon aktif optimum garam S. polycystum 1,50\% dengan karakteristik Mg 29,24 mg/g; Fe 0,15 mg/g; Ca 27,66 mg/g; rasio Na:K 0,87; $\mathrm{NaCl} 33,87 \%$; dan nilai $\mathrm{IC}_{50} 201,0 \mathrm{mg} / \mathrm{L}$. Konsentrasi karbon aktif optimum garam P. minor yaitu $1 \%$ dengan karakteristik Mg 39,05 mg/g; Fe 0,03 mg/g; Ca 32,28 mg/g; rasio Na:K 1,97; $\mathrm{NaCl} 28,34 \%$ dan nilai IC50 $111,39 \mathrm{mg} / \mathrm{L}$.

Kata kunci: aroma, hipertensi, garam diet, mineral, $\mathrm{NaCl}$,rasio $\mathrm{Na}: \mathrm{K}$

\section{Effectiveness of Active Carbon in the Production of Brown Seaweed Salt (Sargassum polycystum and Padina minor)}

\begin{abstract}
Brown seaweed has the potential to developed as a source of salt for hypertension, but the distinctive aroma of seaweed is still an obstacle in the final product. One way that can be done in minimizing these problems is the addition of natural material that play a role in eliminating odors. Activated carbon is a natural and non-toxic material that can be used to reduce the aroma and act as adsorbent. The purpose of this research is to determine the concentration of activated carbon in the process of making S. polycystum and P. minor salts to produce salt that is acceptable to the public. The method used with different concentrations of activated carbon $(0 \%, 0.50 \%, 0.75 \%, 1 \%, 1.25 \%, 1.50 \%(\mathrm{w} / \mathrm{v}))$ in the salt making process, sensory test of aroma and characterization of seaweed salt. Salt characteristics include mineral content $(\mathrm{Mg}, \mathrm{Fe}, \mathrm{Ca}$, $\mathrm{Na}, \mathrm{K}), \mathrm{Na}: \mathrm{K}$ ratio, $\mathrm{NaCl}$ content and antioxidant activity. The optimum activated carbon concentration of S. polycystum salt is $1.50 \%$ with $\mathrm{Mg} 29.24 \mathrm{mg} / \mathrm{g}$; Fe $0.15 \mathrm{mg} / \mathrm{g}$; Ca $27.66 \mathrm{mg} / \mathrm{g}$; Na:K ratio 0.87; $\mathrm{NaCl} 33.87 \%$; $\mathrm{IC}_{50}$ value $201.0 \mathrm{mg} / \mathrm{L}$. The optimum concentration of activated carbon of $P$. minor salt is $1 \%$ with $\mathrm{Mg} 39.05$ $\mathrm{mg} / \mathrm{g}$; Fe $0.03 \mathrm{mg} / \mathrm{g}$; Ca $32.28 \mathrm{mg} / \mathrm{g}$; Na:K ratio 1.97; $\mathrm{NaCl} 28.34 \%$ and IC50 value $111.39 \mathrm{mg} / \mathrm{L}$.
\end{abstract}

Keywords: aroma, dietary salt, hypertension, mineral, $\mathrm{NaCl}, \mathrm{Na}: \mathrm{K}$ ratio 


\section{PENDAHULUAN}

Rumput laut mengandung protein, lipid, karbohidrat, mineral, vitamin, dan komponen bioaktif (Diachanty et al. 2017; Nufus et al. 2017; Manteu et al. 2018). Rumput laut telah banyak dimanfaatkan sebagai bahan baku produk kosmetik (Nurjanah et al. 2016) yaitu calir raga/body lotion (Nurjanah et al. 2020a; Nurjanah et al. 2021), lulur (Nurjanah et al. 2021a), tabir surya (Yanuarti et al 2021; Nurjanah et al 2019a; Nurjanah et al 2017; Yanuarti et al 2017; Luthfiyana et al 2016), lightening (Sari et al. 2019; Dolorosa et al. 2019), (Nurjanah et al. 2018a), masker peel off (Nurjanah et al 2019b), dan masker jerawat (Nurjanah et al 2018b) dan produk pangan salah satunya garam rumput laut (Nurjanah et al. 2021b; Nurjanah et al. 2021c; Nurjanah et al. 2020b; Kurniawan et al. 2019; Nufus et al. 2019; Nurjanah et al. 2018c).

Rumput laut mengandung senyawa metabolit primer dan sekunder yang baik untuk aktivitas biologis tubuh. Senyawa yang terdapat dari berbagai jenis rumput laut khususnya rumput laut cokelat memiliki sifat antibakteri, antioksidan, antiinflamasi, antikoagulan, antivirus, antijamur, dan aktivitas apoptosis (Admassu et al. 2015; Gazali et al. 2019a; Gazali et al. 2019b). Menurut Manteu et al. (2018) rumput laut cokelat Sargassum polycystum dan Padina minor memiliki komposisi nutrisi, kandungan mineral ( $\mathrm{Mg}, \mathrm{Fe}, \mathrm{K}, \mathrm{Na}, \mathrm{Ca})$, dan senyawa bioaktif (flavonoid, saponin, steroid, alkaloid, fenol, triterponoid), sehingga dapat dimanfaatkan sebagai bahan baku pangan fungsional garam bagi penderita hipertensi.

Hipertensi merupakan faktor utama penyakit kardiovaskular, serebrovaskular, serta gagal ginjal. Penyakit hipertensi dipengaruhi oleh beberapa faktor di antaranya yaitu faktor internal berupa jenis kelamin, genetika, dan umur, serta faktor eksternal yaitu kurang olahraga, stres, konsumsi garam, dan obesitas (Mamamit et al. 2017). Badan kesehatan dunia (WHO), mengajurkan penderita hipertensi untuk membatasi konsumsi garam dapur, karena dengan asupan garam yang terus menerus dapat meningkatkan risiko hipertensi. Konsumsi garam tidak lebih dari $100 \mathrm{mEq} / \mathrm{L}(2,4 \mathrm{~g}$ garam natrium atau
6 g garam dapur) sehari terindikasi dapat menurunkan tekanan darah sistolik 2-8 $\mathrm{mmHg}$ (Alberta et al. 2014). Garam diet adalah garam beryodium yang berbentuk cairan atau padatan dengan kadar $\mathrm{NaCl}$ maks $60 \%$ yang dapat dikonsumsi langsung oleh masyarakat (PERMEN 2014) dan merupakan salah satu produk alternatif untuk terapi diet penyakit hipertensi (Nurlita et al. 2017). Rumput laut berpotensi sebagai bahan baku garam diet untuk pencegahan penyakit hipertensi dan hidup sehat yang berkualitas (Nurjanah et al. 2021b; Nurjanah et al. 2021c; Nurjanah et al. 2020b; Kurniawan et al. 2019; Nufus et al. 2019; Nurjanah et al. 2018c). Namun, kendala dalam pengembangan rumput laut untuk bahan baku garam rumput laut adalah bau atau aroma rumput laut (amis) yang kuat pada produk akhir yang dihasilkan.

Karbon aktif merupakan salah satu bahan alami yang dapat digunakan dalam meminimalisasi bau pada garam diet rumput laut. Karbon aktif mengandung mikropori, mesopori, dan makropori dalam strukturnya yang memiliki peran dalam menentukan kinerja karbon aktif sebagai adsorben, pengolahan sumber air, serta penghilang warna dan bau (Yahya 2018; Lubis et al. 2020). Penggunaan karbon aktif merupakan perlakuan yang paling efektif dalam menghilangkan senyawa volatil fukoidan yang diisolasi dari rumput laut Sargassum sp. (Khalafu 2017). Penggunaan arang aktif dalam proses filtrasi dapat menghilangkan bau dan rasa pada air (Fadhillah et al. 2016). Oleh karena itu, perlu adanya penelitian terkait pengaruh penambahan karbon aktif pada produk akhir garam rumput laut S. polycystum dan P. minor. Tujuan penelitian ini adalah menentukan konsentrasi karbon aktif untuk menurunkan aroma amis, serta menentukan karakteristik garam rumput laut S. polycystum dan P. minor.

\section{BAHAN DAN METODE Bahan dan Alat}

Bahan baku yang digunakan dalan penelitian adalah rumput laut $S$. polycystum dan $P$. minor diperoleh dari perairan Pohuwato Provinsi Gorontalo yang merupakan rumput laut non budi daya. Karbon aktif dari 
Laboratorium Residu Bahan Agrokimia, Ciomas, Bogor. Bahan kimia yang digunakan adalah $\mathrm{H}_{2} \mathrm{SO}_{4}$ (Merck), $\mathrm{HNO}_{3}$ (Merck), akuades, $\mathrm{HCl}$ (Merck), etanol grade pro analys (PA), asam askorbat (Merck), asam galat (Merck) reagen folin (Merck), dan 2,2-difenil1-pikrilhidrazil (DPPH) (Sigma-Aldrich).

Alat yang digunakan adalah blender (miyako CH-501, China), penangas air/water bath (WSB 18L, Korea South), kertas saring, nylon mesh 500, oven listrik, alat kocok/shaker (SHO-1D), alat-alat gelas (Pyrex, Japan), mikro pipet (Gilson, Swiss), Atomic Absorbtion Spectrophotometer (AAS) (Shimadzu AA7000) Uv-Vis RS Spectrophotometer (UV2500).

\section{Metode Penelitian \\ Pengambilan dan preparasi sampel}

Rumput laut S. polycystum dan P. minor diambil dari perairan Pohuwato. Rumput laut cokelat segar dicuci dengan air laut untuk dibersihkan dari pasir, kemudian rumput laut dikeringkan dengan cara dianginanginkan selama 5-7 hari. Rumput laut kering dihaluskan menggunakan blender hingga halus dan dilakukan pengayakan menggunakan saringan dengan ukuran 100 mesh, dan dihasilkan tepung rumput laut.

\section{Pembuatan garam rumput laut}

Pembuatan garam rumput laut mengacu Nurjanah et al. (2018). Tepung rumput laut ditambahkan akuades yang telah dipanaskan terlebih dahulu pada suhu 40 (1:10). Sampel diletakkan dalam penangas air kocok (shaker water bath) selama 10 menit, kemudian dilakukan penyaringan dua kali menggunakan nylon mesh 500 dan kertas saring (Whatman No 42), selanjutnya filtrat ditambahkan karbon aktif dengan konsentrasi 0\% (kontrol), 0,50\%, 0,75\%, 1\%, 1,25\%, 1,50\% (b/v), kemudian dikocok selama 12 jam dan disaring kembali menggunakan kertas saring (Whatman No 42). Filtrat yang dihasilkan dikeringkan menggunakan oven dengan suhu 60 sampai kering selama \pm 48 jam.

\section{Analisis rendemen}

Perhitungan rendemen bertujuan untuk mengetahui persentase garam yang dihasilkan. Nilai rendemen diperoleh dari perbandingan garam rumput laut yang dihasilkan dengan jumlah bahan baku yang digunakan. Perhitungan rendemen mengacu pada Sudarmadji et al. (2003) menggunakan rumus berikut:

Rendemen $=\quad \frac{\text { berat akhir yang dihasilkan }(\mathrm{g})}{\text { berat sampel awal }(\mathrm{g})} \times 100 \%$

\section{Analisis kadar mineral}

Analisis mineral garam rumput laut cokelat terdiri atas $\mathrm{Na}, \mathrm{K}, \mathrm{Ca}, \mathrm{Fe}, \mathrm{Mg}$ mengacu pada AOAC (2005; 984.27) menggunakan Atomic Absorbtion Spectrophotometer (AAS). Sampel tepung rumput laut $1 \mathrm{~g}$ ditambahkan $5 \mathrm{~mL} \mathrm{HNO}_{3}$ dan didiamkan selama 1 jam pada suhu ruang asam, kemudian campuran tersebut dipanaskan dengan lempeng hangat dengan temperatur rendah selama 4-6 jam. Sampel kemudian ditutup dan dibiarkan semalam, setelah itu, ditambah $0,4 \mathrm{~mL} \mathrm{H}_{2} \mathrm{SO}_{4}$ dan dipanaskan di atas lempeng hangat sampai larutan berkurang atau lebih pekat (biasanya \pm 1 jam) dan ditambahkan 2-3 tetes larutan campuran $\mathrm{HClO}_{4}: \mathrm{HNO}_{3}$ dengan perbandingan 2:1. Sampel tetap diletakkan di atas lempeng hangat karena pemanasan tetap dilanjutkan sampai ada perubahan warna dari cokelat menjadi kuning muda, setelah ada perubahan warna, pemanasan masih dilanjutkan selama 10-15 menit. Sampel didinginkan, ditambah $2 \mathrm{~mL}$ akuades dan 0,6 $\mathrm{mL} \mathrm{HCl}$. Larutan hasil pengabuan basah ditera ke dalam labu takar $100 \mathrm{~mL}$ menggunakan air demineral.. Hasil pengabuan basah dianalisis di Atomic Absorbtion Spectrofotometer (AAS) dengan masing-masing panjang gelombang yang digunakan adalah $\mathrm{Na} 589,6 \mathrm{~nm}, \mathrm{Ca} 422,7$ nm, Fe 248,3 nm, Mg 285,2 nm, K 766,5 nm.

\section{Pengujian sensori aroma}

Uji organoleptik atau uji sensori merupakan cara pengujian menggunakan indra manusia sebagai alat utama untuk pengukuran daya penerimaan terhadap produk. Uji sensori parameter aroma untuk garam rumput laut $S$. polycystum dan $P$. minor menggunakan metode SNI 01-2346-2006 dengan 25 panelis semi terlatih. 


\section{Analisis kadar garam ( $\mathrm{NaCl})$}

Analisis kadar garam diet $S$. polycystum dan P. minor mengacu pada SNI (3556:2016). Garam rumput laut cokelat $5 \mathrm{~g}$ ditambahkan akuades $200 \mathrm{~mL}$ dalam labu ukur $500 \mathrm{~mL}$, kemudian sampel disaring menggunakan kertas saring. Hasil air saringan dan kertas saring dicuci dengan akuades ( $1 \mathrm{x}$ semprot) dan diencerkan sampai tera. Sampel kemudian ditambahkan dengan beberapa tetes $\mathrm{H}_{2} \mathrm{SO}_{4}$ $1 \mathrm{~N}$ sampai larutan bereaksi asam terhadap indikator fenolftalein, selanjutnya dinetralkan dengan $\mathrm{NaOH} 4 \mathrm{~N}$ dan diencerkan dengan air akuades sampai $100 \mathrm{~mL}$. Sampel ditambahkan $1 \mathrm{~mL}$ larutan $\mathrm{K}_{2} \mathrm{CrO}_{4} 5 \%$ dan titrasi dengan larutan $\mathrm{AgNO}_{3} 0,1 \mathrm{~N}$ sampai terbentuk warna merah bata. Perhitungan untuk mengetahui $\mathrm{NaCl}$ menggunakan rumus berikut:

$$
\begin{aligned}
& \text { Kadar } \mathrm{NaCl}=\frac{\mathrm{v} \times \mathrm{N} \times \mathrm{fp} \times 58.5}{\cdots} \times 100 \\
\text { Ket. } \mathrm{V}= & \text { volume } \mathrm{AgNO}_{3} \text { yang diperlukan } \\
& \text { pada titrasi }(\mathrm{mL}) \\
\mathrm{N} & =\text { normalitas } \mathrm{AgNO}_{3}(\mathrm{~N}) \\
\mathrm{Fp} & =\text { faktor pengencer } \\
58.5 \quad= & \text { bobot molekul } \mathrm{NaCl} \\
\mathrm{W} & =\text { bobot contoh uji }(\mathrm{mg})
\end{aligned}
$$

\section{Uji aktivitas antioksidan}

Pengujian aktivitas antioksidan dengan metode radikal DPPH mengacu pada Moleneux (2004). Sampel dilarutkan dalam etanol dengan konsentrasi 10; 25; 50; 75; 100 ppm. Asam askorbat sebagai kontrol positif dibuat dengan kosentrasi $1 ; 2 ; 3 ; 4$ dan 5 ppm. Masing-masing sampel diukur pada panjang gelombang $517 \mathrm{mn}$ menggunakan spektrofotometer.

\section{Analisis Data}

Rancangan percobaan yang digunakan adalah Rancangan Acak Lengkap (RAL) untuk data rendemen dan rasio Na:K dengan perlakuan karbon aktif $0 \%, 0,50 \%, 0,75 \%, 1 \%$, $1,25 \%$. Data yang diperoleh dilakukan analisis ANOVA. Perhitungan nilai sensori aroma dilakukan dengan menggunakan analisis nonparametri yaitu uji Kruskal-Wallis dengan menggunakan SPSS (Statistical Process for Social Science). Hasil uji berbeda nyata $p<0,05$ maka dilanjutkan dengan uji Duncan. Data dianalisis menggunakan perangkat lunak SPSS 22.0.

\section{HASIL DAN PEMBAHASAN \\ Rendemen dan rasio Na:K garam diet}

Analisis rendemen dilakukan untuk mengetahui bobot akhir garam yang dihasilkan dari tepung $S$. polycystum dan P. minor dengan perlakuan karbon aktif. Hasil perhitungan rendemen garam rumput laut dan mineral dapat dilihat pada Table 1. Nilai rendemen garam S. polycystum yaitu 20,02$20,47 \%$. Berdasarkan hasil analisis varian (ANOVA) bahwa konsentrasi karbon aktif berbeda tidak memberikan pengaruh yang nyata $(p>0,05)$ terhadap persentase rendemen garam $S$. polycystum.

Nilai rendemen produk garam $P$. minor yaitu 19,96-22,62\%. Berdasarkan analisis varian (ANOVA) bahwa konsentrasi karbon aktif yangberbeda memberikan pengaruh yang nyata $(p<0,05)$ terhadap nilai produk garam $P$. minor. Perlakuan kontrol tidak berbeda nyata dengan perlakuan $0,50 \%$ berdasarkan hasil uji lanjut Duncan, sedangkan perlakuan $0,75 \%, 1 \%, 1,25 \%, 1,50 \%$ berbeda nyata. Hal ini kemungkinan adanya penambahan

Table 1 Yield value and ratio of $\mathrm{Na}: \mathrm{K}$

\begin{tabular}{lrrrr}
\hline \multirow{2}{*}{ Sample } & \multicolumn{2}{c}{ Yield value (\%) } & \multicolumn{2}{c}{ Na:K ratio } \\
\cline { 2 - 5 } & S. polycystum & P. minor & S. polycystum & P. minor \\
\hline Control & $20.47^{\mathrm{a}}$ & $22.62^{\mathrm{a}}$ & $1.33^{\mathrm{a}}$ & $2.15^{\mathrm{a}}$ \\
Active carbon $0.50 \%$ & $20.40^{\mathrm{a}}$ & $22.02^{\mathrm{ab}}$ & $1.19^{\mathrm{c}}$ & $2.08^{\mathrm{b}}$ \\
Active carbon $0.75 \%$ & $20.02^{\mathrm{a}}$ & $20.82^{\mathrm{bc}}$ & $1.25^{\mathrm{b}}$ & $2.04^{\mathrm{b}}$ \\
Active carbon $1 \%$ & $20.07^{\mathrm{a}}$ & $20.05^{\mathrm{c}}$ & $1.17^{\mathrm{c}}$ & $1.97^{\mathrm{c}}$ \\
Active carbon $1.25 \%$ & $20.25^{\mathrm{a}}$ & $19.96^{\mathrm{c}}$ & $1.04^{\mathrm{d}}$ & $1.82^{\mathrm{e}}$ \\
\hline
\end{tabular}

${ }^{*}$ The numbers followed by the same letter were not significantly different $(p<0.05)$ (Duncan's test). 
konsentrasi karbon aktif, selanjutnya dilakukan proses penyaringan yang berulang sehingga ada massa yang hilang dalam proses penyaringan tersebut yaitu filtrat yang tidak tersaring semua, serta pada proses akhir penggerusan garam.

Kandungan mineral pada garam rumput laut terutama mineral natrium dan kalium merupakan mikronutrien yang memiliki peran penting dalam hipertensi, hal ini dikarenakan meningkatnya asupan natrium dalam jangka waktu tertentu dan ketidakseimbangan jumlah kalium (K). Rodrigues et al. (2015) menjelaskan bahwa rumput laut dengan rasio $\mathrm{Na}: \mathrm{K}$ rendah kemungkinan bisa digunakan sebagai pengganti garam.

Nilai rasio Na:K garam S. polycystum yaitu 0,87-1,25 dan P. minor 1,82-2,15. Berdasarkan hasil ANOVA bahwa konsentrasi karbon aktif yang berbeda memberikan pengaruh yang nyata $(\mathrm{p}<0.05)$ terhadap nilai rasio $\mathrm{Na}: \mathrm{K}$ garam S. polycystum. Perlakuan 0,5\% dan $1 \%$ menunjukkan nilai yang tidak berbeda nyata sedangkan perlakuan kontrol 0,75\%, 1,25\%, $1,50 \%$ menunjukkan nilai yang berbeda nyata berdasarkan hasil uji lanjut Duncan. Sedangkan hasil ANOVA bahwa konsentrasi karbon aktif yang berbeda memberikan pengaruh yang nyata $(p<0,05)$ terhadap rasio Na:K garam $P$. minor. Perlakuan $0,5 \%$ dan $0,75 \%$ menunjukkan nilai yang tidak berbeda nyata sedangkan perlakuan kontrol, $1 \%, 1,25 \%, 1,50 \%$ menunjukkan nilai yang berbeda nyata berdasarkan hasil uji lanjut Duncan. Rasio Na:K dengan adanya perlakuan konsentrasi karbon aktif yang berbeda, yaitu semakin tinggi konsentrasi karbon aktif nilai rasio Na:K menurun. Karbon aktif memiliki sifat adsorpsi yang mungkin menjadi salah satu faktor terjadinya penurunan rasio Na:K. Arsad dan Hamdi (2010) menyatakan bahwa karbon aktif memiliki sifat selektif, tergantung pada besar atau volume pori-pori dan luas permukaan dan mengadsorpsi gas dan senyawa-senyawa kimia tertentu.

Nilai rasio Na:K garam $S$. polycystum dan $P$. minor dengan konsentrasi karbon aktif $1 \%, 1,25 \%$, dan 1,50\% memenuhi rekomendasi rasio Na:K yang dianjurkan World Health Organization (WHO) yaitu rasio $\mathrm{Na}$ :K orang dewasa sekitar 1,0 sampai $<2,0$ (Yatabe et al. 2017). Kelebihan natrium dan kalium yang tidak mencukupi dapat menyebabkan peningkatan tekanan darah. Adanya hubungan antara rasio asupan natrium:kalium yang tinggi akan meningkatkan risiko terkena hipertensi (Gutami dan Kumala 2021), dengan memenuhi rasio natrium:kalium yang sesuai dapat mengurangi prevalensi terjadinya hipertensi (WHO 2012).

\section{Nilai sensori aroma garam S. polycystum dan P. minor}

Aroma merupakan salah satu parameter pengujian analisis sensorik menggunakan penciuman. Aroma dapat diterima jika bahan yang dihasilkan memimiliki bau yang khas, selain itu komponen yang dapat menimbulkan aroma adalah senyawa volatil. Hasil sensori dapat dilihat pada Table 2.

Hasil uji Kruskal-wallis menunjukkan bahwa konsentrasi karbon aktif yang berbeda pada filtrat memberikan pengaruh pada

Table 2 Sensory value of dietary salt aroma

\begin{tabular}{lrc}
\hline \multirow{2}{*}{ Sample } & \multicolumn{2}{c}{ Sensory value } \\
\cline { 2 - 3 } & S. polycystum & P. minor \\
\hline Control & $5.40^{\mathrm{b}}$ & $4.85^{\mathrm{d}}$ \\
Active carbon 0.50\% & $5.50^{\mathrm{b}}$ & $5.10^{\mathrm{cd}}$ \\
Active carbon 0.75\% & $6.15^{\mathrm{ab}}$ & $6.00^{\mathrm{ab}}$ \\
Active carbon 1\% & $5.95^{\mathrm{ab}}$ & $6.55^{\mathrm{a}}$ \\
Active carbon 1.25\% & $5.40^{\mathrm{b}}$ & $5.60^{\mathrm{bcd}}$ \\
Active carbon $1.50 \%$ & $6.55^{\mathrm{a}}$ & $5.90^{\mathrm{abc}}$ \\
\hline${ }^{*}$ The numbers followed by the same letter were not significantly different \\
$(p<0.05$ ) (Duncan's test).
\end{tabular}


tingkat kesukaan aroma garam rumput laut S. polycystum dan P. minor. Nilai hedonik aroma garam S. polycystum konsentrasi 1,50\% memiliki nilai rata-rata tertinggi yaitu 6,55 (suka) dengan kriteria aroma rumput laut berkurang. Konsentrasi karbon aktif 0,75\%, $1 \%$ dan $1,5 \%$ tidak memberikan pengaruh pada nilai aroma, hal ini kemungkinan karena kapasitas adsorpsi karbon aktif tergantung pada sifat adsorben, sifat kondisi adsorbat, larutan. Faktor yang memengaruhi daya serap karbon aktif yaitu, sifat arang aktif, sifat komponen daya serapnya, sifat larutan, dan sistem kontak (Polii 2017).

Garam P. minor dengan konsentrasi karbon aktif $1 \%$ memiliki nilai rata-rata tertinggi yaitu 6,55 (suka) dengan kriteria aroma rumput laut berkurang. Hal ini menandakan bahwa penambahan karbon aktif pada filtrat rumput laut dapat meminimalisasi bau dan dapat diterima panelis. Perlakuan karbon aktif dengan konsentrasi 1,25\% dan $1,50 \%$ memiliki nilai aroma yang rendah, hal ini kemungkinan terjadi karena daya adosorpsi menurun. Kurniawan et al. (2019) menyatakan bahwa perlakuan karbon aktif 0,5 dan $1,5 \%$ pada garam rumput laut memperoleh daya terima panelis dengan nilai berada pada angka 5 (suka). Di antara sifat-sifat karbon aktif, distribusi pori adalah yang paling penting memengaruhi adsorpsi. Adsorpsi adalah terjadinya proses konsentrasi suatu zat pada permukaan zat lain, zat yang menyerap disebut adsorben sedang zat yang diserap seperti molekul, atom atau ion disebut adsorbat (Pohan 1993). Penurunan aroma garam diet $S$. polycystum dan P. minor dilakukan dengan media saring karbon aktif.

\section{Karakterisasi garam S. polycystum dan $\boldsymbol{P}$. minor}

Karakterisasi produk dilakukan pada konsentrasi karbon aktif yang memperoleh daya terima panelis dari nilai sensori. Berdasarkan nilai sensori aroma pada garam rumput laut S. polycystum (1,50\%) dan P. minor (1\%) memperoleh daya terima 6 yang artinya disukai panelis. Hasil analisis kadar $\mathrm{NaCl}$ garam $S$. polycystum konsentrasi $1,50 \%$ yaitu $33,87 \%$ dan garam $P$. minor konsentrasi $1 \%$ yaitu $28,34 \%$. Hasil analisis
$\mathrm{NaCl}$ garam S. polycystum dan P. minor masuk dalam kategori garam diet yang sesuai dengan standar yaitu kandungan $\mathrm{NaCl}$ maksimal $<60 \%$ (Permenperin 2014). Garam diet dapat digunakan sebagai terapi untuk penyakit hipertensi, karenapenderitahipertensi dibatasi mengonsumsi makanan dengan kadar $\mathrm{NaCl}$ tinggi. Adanya hubungan antara konsumsi garam (natrium atau natrium klorida) dan tekanan darah tinggi yaitu semakin banyak jumlah garam dalam makanan, maka semakin tinggi risiko hipertensi. Badan kesehatan dunia WHO, Diet Dietary to Stop Hypertension (DASH), dan kelompok internasional lainnya merekomendasikan pengurangan konsumsi natrium untuk menurunkan tekanan darah. Kadar karakteristik garam dapat dilihat pada Tabel 3.

Garam S. polycystum dan P. minor mengandung kadar mineral tinggi dibandingkan garam konsumsi. Lee et al. (2016) melaporkan garam komsumsi mengandung $\mathrm{NaCl} 85,7 \%$, kalsium 1,5 $\mathrm{mg} / \mathrm{g}$, kalium 2,9 $\mathrm{mg} / \mathrm{g}$ dan magnesium 3,9 mg/g. Mineral Ca, Mg, dan K pada garam rumput laut berfungsi dalam proses penurunan tekanan darah dengan melakukan proses penghambatan melalui mekanisme penyempitan pada pembuluh darah sehingga terjadinya penurunan resistensi perifer. Nilai rasio $\mathrm{Na}$ K pada garam diet memiliki peran dalam pencegahan dan pengendalian hipertensi (Atun et al. 2014).

Hasil uji aktivitas antioksidan garam P. minor $\mathrm{IC}_{50}$ yaitu $111,39 \mathrm{mg} / \mathrm{L}$ dengan kategori sedang dan garam $S$. polycystum $\mathrm{IC}_{50}$ yaitu 201,0 mg/L kategori sangat lemah. Kategori antioksidan dapat dibedakan menjadi sangat kuat dengan nilai $\mathrm{IC}_{50}<50$ $\mathrm{mg} / \mathrm{mL}$, kuat dengan nilai $\mathrm{IC}_{50} 50-100 \mathrm{mg} /$ $\mathrm{mL}$, sedang dengan nilai $\mathrm{IC}_{50} 100-150 \mathrm{mg} /$ $\mathrm{mL}$, lemah dengan nilai $\mathrm{IC}_{50} 150-200 \mathrm{mg} /$ $\mathrm{mL}$, dan sangat lemah dengan nilai $\mathrm{IC}_{50}<200$ $\mathrm{mg} / \mathrm{mL}$ (Molyneux 2004). Nilai $\mathrm{IC}_{50}$ garam meningkat bila dibandingkan dengan nilai $\mathrm{IC}_{50}$ bahan baku rumput laut cokelat, hal ini kemungkinan adanya penambahan karbon aktif yang dapat menghilangkan senyawa fenol yang berpotensi sebagai antioksidan. Kurniawan et al. (2019) melaporkan aktivitas antioksidan garam rumput laut U. lactuca 
Table $3 \mathrm{NaCl}$ content, minerals and antioxidant activity

\begin{tabular}{|c|c|c|c|}
\hline \multirow[b]{2}{*}{ Parameter } & \multicolumn{3}{|c|}{ Seaweed salt } \\
\hline & $\begin{array}{l}\text { S. polycystum } \\
\text { Active carbon } 1.50 \%\end{array}$ & $\begin{array}{c}\text { P. minor } \\
\text { Active carbon } 1 \%\end{array}$ & $\begin{array}{c}\text { Salt } \\
\text { consumption }^{\mathrm{a}}\end{array}$ \\
\hline $\mathrm{NaCl}$ content (\%) & 33.87 & 28.34 & 85.7 \\
\hline \multicolumn{4}{|c|}{ Mineral content (mg/g) } \\
\hline Magnesium (Mg) & 29.24 & 39.05 & 3.9 \\
\hline Iron $(\mathrm{Fe})$ & 0.15 & 0.03 & - \\
\hline Calcium (Ca) & 27.66 & 32.28 & 1.5 \\
\hline Potassium (K) & 91.79 & 35.05 & - \\
\hline Sodium $(\mathrm{Na})$ & 80.28 & 69.24 & - \\
\hline Na:K ratio & & 1.97 & - \\
\hline $\mathrm{IC}_{50}(\mathrm{mg} / \mathrm{L})$ & 201.00 & 111.39 & - \\
\hline
\end{tabular}

dengan perlakuan arang aktif 1,5\% yaitu $\mathrm{IC}_{50} 1681,27 \mathrm{mg} / \mathrm{L}$. Khalafu et al. (2017) melaporkan penambahan karbon aktif pada fukoidan Sargassum sp. dengan konsentrasi berbeda dapat menurunkan nilai total fenol, karena salah satu mekanisme karbon aktif adalah untuk menghilangkan senyawa fenolik.

Nilai aktivitas antioksidan DPPH selain dipengaruhi oleh karbon aktif, dapat dipengaruhi juga oleh proses pemanasan. Diachanty (2018) melaporkan meningkatnya nilai aktivitas antioksidan DPPH dan menurunnya aktivitas antioksidan pada garam fungsional disebabkan oleh pengaruh suhu dan waktu pemanasan pada proses pembuatan garam fungsional. Antioksidan adalah agen yang menghambat oksidasi dan menetralisasi radikal bebas (Abdullah et al. 2020), sehingga tidak terjadi stres oksidatif yang akhirnya meningkatkan bioavailabilitas nitric oxida (NO) (Jawa dan Yasa 2012). Pemberian antioksidan dapat meningkatkan kemampuan platelet dalam melakukan pelepasan NO sehingga menyebabkan penurunan tekanan darah dan juga melakukan penghambatan proses pembentukan trombus (Freedman et al. 2001). Villaverde et al. (2019) menyatakan bahwa keseimbangan antara antioksidan alami dalam makanan bisa lebih efisien untuk mencegah hipertensi, daripada suplemen yang dapat menyebabkan kelebihan antioksidan dan menyebabkan ketidakseimbangan sistem anti-oksidatif kompleks.

\section{SIMPULAN}

Karbon aktif dapat meningkatkan nilai sensori aroma garam S. polycystum dan P. minor. Konsentrasi karbon aktif terbaik yaitu konsentrasi 1,50\% garam S. polycystum dengan rasio $\mathrm{Na}: \mathrm{K}$ 0,87, kadar $\mathrm{NaCl} 33,87 \%$, dan nilai $\mathrm{IC}_{50} 201,0 \mathrm{mg} / \mathrm{L}$ aktivitas antioksidan $201,0 \mathrm{mg} / \mathrm{L}$. Garam P. minor konsentrasi 1\% dengan rasio $\mathrm{Na}: \mathrm{K} \mathrm{1,97 \% ,} \mathrm{kadar} \mathrm{NaCl} 28,34 \%$, dan nilai $\mathrm{IC}_{50} 111,39 \mathrm{mg} / \mathrm{L}$.

\section{DAFTAR PUSTAKA}

[AOAC] Association of Analytical Chemist Publisher. 2005. Official methods of analysis of the association of official analytical chemist. ArlingtonVirginia USA: The Association of Official Analytical Chemist, Inc.

[PERMENPERIN] Peraturan Mentri Perindustrian. 2014. Perubahan atas peraturan mentri perindustrian No 134/M/IND/PER/10/2009 tentang peta panduan (road map) pengembangan klaster industri garam.

Abdullah A, Nurjanah, Seulalae AV. 2020. Antioxidant activity of biopigment fractions from golden apple snail eggs 
(Pomacea canaliculata). IOP Confierence Series : Earth and Environmental Science. 404: 1-14.

Admassu H, Zhao W, Yang R, Gasmalla MAA, Alsir E. 2015. Development of functional foods: seaweeds (Algae) untouched potential and alternative resource - a review. International Journal of Scientific \& Technology Research. 4(9):108-117.

Alberta LT, Proboningsih J, Almahmuda M. 2014. Peningkatan perilaku diet rendah garam berbasis theory of planned behavior (TPB) pada lansia penderita hipertensi. Jurnal Ners. 9 (2):297-304.

Arsad E, Hamdi S. 2010. Teknologi pengolahan dan pemanfaatan karbon aktif untuk industri. Jurnal Riset Industri Hasil Hutan. 2(2):43-51.

Atun L, Siswati T, Kurdanti W. 2014. Asupan sumber natrium, rasio kalium natrium, aktivitas fisik, dan tekanan darah pasien hipertensi. Media Gizi Mikro Indonesia. 6 (1): 63-71.

Diachanty S, Nurjanah, Abdullah A. 2017. Aktivitas antioksidan berbagai jenis rumput laut cokelat dari perairan Kepulauan Seribu. Jurnal Pengolahan Hasil Perikanan Indonesia. 20 (2): 305318.

Dolorosa MT, Nurjanah, Purwaningsih S, Anwar E. 2019. Utilization of Kappaphycus alvarezii and Sargassum plagyophyllum from Banten as cosmetic creams. IOP Conference Series Earth and Environmental Science. Bogor, Indonesia

Gazali M, Nurjanah, Zamani NP. 2019a. The screening of bioactive compound of the green algae Halimeda macroloba (Decaisne, 1841) as an antioxidant agent from Banyak Island Aceh Singkil. IOP Conference Series Earth and Environmental Science https://iopscience.iop.org/ article/10.1088/1755-1315/348/1/012043. 19-20 Juni 2019.

Gazali M, Zamani NP, Nurjanah. $2019 b$. The potency of green algae Chaetomorpha crassa Agardh as antioxidant agent from coastal of Lhok Bubon, West Aceh, in IOP Conference Series Earth and Environmental
Science https://iopscience.iop.org/ article/10.1088/1755-1315/278/1/012029.

Gutami, Kumala M. 2021. Hubungan rasio asupan natrium berbanding kalium dengan penyakit hipertensi pada lansia. Tarumanagar Medical Journal. 3(2):315322.

Khalafu S, Aida W, Lim SJ, Maskat M. 2017. Effects of deodorisation methods on volatile compounds, chemical properties and antioxidant activities of fucoidan isolated from brown seaweed (Sargassum sp.). Alga Research. 25(1):507-515.

Kurniawan R, Nurjanah, Jacoeb AM, Abdullah A, Pertiwi RM. 2019. Karakteristik garam fungsional dari rumput laut hijau Ulva lactuca. Jurnal Pengolahan Hasil Perikanan Indonesia. 22(3):573-580.

Lee B, Yang A, Kim M, McCurdy S, Boisvert WA. 2016. Natural sea salt comsumption confers profection against hypertension and kidney damage in Dahl salt-sensitive rats. Food and Nutrition Research. 61(1):110.

Lim SJ, Mustapha WA, Maskat MY. 2017. Seaweed Tea: Fucoidan-rich functional food product development from Malaysian brown seaweed, Sargassum binderi. Sains Malaysiana. 46(9):15731579.

Magnusson M, Crarl C, Mata L, Nys R, Paul N. 2016. Seaweed Salt From Ulva: A novel first step in a casscading biorefinery model. Alga Research. 16:308-316.

Manteu SH, Nurjanah, Nurhayati T. 2018. Karakteristik rumput laut cokelat (Sargassum policystum dan Padina minor) dari perairan Pohuwato Provinsi Gorontalo. Jurnal Pengolahan Hasil Perikanan Indonesia. 21(3): 396-405.

Nufus C, Abdullah A, Nurjanah. 2019. Characteristics of green salt as altenative salt for hypertensive patients. IOP Confierence Series : Earth and Environmental Science. 278:1-7.

Nufus C, Nurjanah, Abdullah A. 2017. Karakteristik rumput laut hijau dari perairan Kepulauan Seribu dan Sekotong Nusa Tenggara Barat sebagai antioksidan. Jurnal Pengolahan Hasil Perikanan Indonesia. 20(3):620-632 
Nurjanah, Ramli R L, Jacoeb AM, Seulalae AV. 2021a. Karakteristik fisikokimia dan antioksidan krim lulur kombinasi bubur rumput laut merah (Eucheuma cottonii) dan cokelat (Sargassum sp.). Jurnal Standardisasi. 23(3): 227-240.

Nurjanah, Abdullah A, Darusman HS, Diaresty JVG, Seulalae AV. 2021b. The antioxidant activity of seaweed salt from Sargassum polycystum in Sprague-Dawley male white rats. International Journal of Research in Pharmaceutical Sciences. 12(4): 2601-2609.

Nurjanah, Abdullah A, Rahmadhani A, Seulalae AV. 2021c. Antioxidant activity and combination characteristics of filtrates and Sargassum polycystum seaweed salt residue. Kuwait Journal of Sciences. $\mathrm{x}(\mathrm{x}): 1-12$.

Nurjanah, Abdullah A, Diachanty S. 2020 b. Characteristics of Turbinaria conoides and Padina minor as raw materials for healthy seaweed salt. Pharmacogn Journal. 12(3):624-9.

Nurjanah, Abdullah A, Fachrozan R, Hidayat T. 2018a. Characteristics of seaweed porridge Sargassum sp. and Eucheuma cottonii as raw materials for lip balm. IOP Publishing IOP Conference Series: Earth and Environmental Science. https://iopscience.iop.org/ article/10.1088/1755-1315/196/1/012018.

Nurjanah, Abdullah A, Nufus C. 2018c. Karakteristik sediaan garam Ulva lactuca dari Perairan Sekotong Nusa Tenggara Barat bagi pasien hipertensi. Jurnal Pengolahan Hasil Perikanan Indonesia. 21(1):109-117.

Nurjanah, Aprilia BE, Fransiskayana A, Rahmawati M, Nurhayati T. 2018b. Senyawa bioaktif rumput laut dan ampas teh sebagai antibakteri dalam formula masker wajah. Jurnal Pengolahan Hasil Perikanan Indonesia. 20:305-318.

Nurjanah, Fauziyah S, Abdullah A. 2019b. Karakteristik bubur rumput laut Eucheuma cottonii dan Turbinaria conoides sebagai bahan baku masker peel off. Jurnal Pengolahan Hasil Perikanan Indonesia. 22:391-402.

Nurjanah, Jacoeb AM, Bestari E, Seulalae
AV. 2020a. Karakteristik bubur rumput laut Gracilaria verrucosa dan Turbinaria conoides sebagai bahan baku body lotion. Jurnal Akuatek. 1:73-83.

Nurjanah, Jacoeb AM, Ramlan, Abdullah A. 2020b. Penambahan genjer (Limnocharis flava) pada pembuatan garam rumput laut hijau untuk penderita hipertensi. Jurnal Pengolahan Hasil Perikanan Indonesia. 23(3):459-469.

Nurjanah, Nurilmala M, Abdullah A, Seulalae AV, Fauzan R. 2021. Characteristics of Eucheuma denticulatum and Turbinaria conoides porridge as body lotion materials. International Journal Agricultural and Technology. 17(4):1521-1536.

Nurjanah, Nurilmala M, Anwar E, Luthfiyana $\mathrm{N}$, Hidayat T. 2017. Identification of bioactive compounds of seaweed Sargassum sp. and Eucheuma cottonii doty as a raw sunscreen cream. Proceedings of the Pakistan Academy of Sciences: Pakistan Academy of Sciences B. Life and Environmental Sciences. 54: 311-318.

Nurjanah, Nurilmala M, Hidayat T, Sudirdjo F. 2016. Characteristics of seaweed as raw materials for cosmetics. Aquatic Procedia. 7: 177-180.

Nurjanah, Suwandi R, Anwar E, Maharany F, Hidayat T. 2019a. Characterization and formulation of sunscreen from seaweed Padina australis and Euchema cottonii slurry. IOP Conference Series Earth Environmental Sciences. https://iopscience.iop.org/ article/10.1088/1755-1315/404/1/012051.

Nurlita N, Nelli S, Lipinwati. 2017. Pengetahuan pasien hipertensi terhadap diet rendah garam sebelum dan sesudah diberikan konsultasi gizi di poli rumah sakit radem mattaher Tahun 2017. Jurnal Manajemen Jayanegara. 5(2):117-126.

Rodrigues D, Freitas AC, Pereira L, RochaSantos TA, Vasconcelos M, Roriz M, Rodriguez-Alcala L, Gomes AM, Duarte A. 2015. Chemical composition of red, brown and green macroalgae from buarcos bay in central west Coast of Portugal. Food Chemistry. 183:197-207.

Villaverde P, Lajous M, MacDonald CJ, Fagherazzi G, Bonnet F, Boutron-Ruault 
MC. 2019. High diatery total antioxidant capacity is associated with a reduced risk of hypertension in French women. Nutrition Journal. 18 (31).

Yatabe MS, Iwahori T, Watanabe A, Kozue T, Sanada H, Watanabe T, Ichihara A, Felder RA, Miura K, Ueshima H et al. 2017. Urinary sodium-to-potassium ration tracks the changes in salt intake during an experimental feeding study using standardized low-salt an high-salt meals among healthy Japanese Volunteers. Journal Nutrients. 9(951):2-13.

Yanuarti R, Nurjanah, Anwar E, Hidayat T. 2017b. Profil fenolik dan aktivitas antioksidan dari ekstrak rumput laut Turbinaria conoides dan Eucheuma cottonii. Jurnal Pengolahan Hasil Perikanan Indonesia. 20(2): 230-237. 